\title{
Correction to: 25 -Hydroxyvitamin D potentializes extracellular cathelicidin release from human PBMC stimulated ex vivo with either bacterial (LPS) or viral (P:IC) mimetics
}

\author{
Sahar Aldekwer ${ }^{1}$. Nicolas Goncalves-Mendes ${ }^{1} \cdot$ Rea Bingula $^{1}$. Guillaume Martinroche ${ }^{1} \cdot$ Kassandra Lanchais $^{1}$. \\ Stéphanie Rougé ${ }^{1} \cdot$ Marie-Chantal Farges $^{1} \cdot$ Adrien Rossary $^{1} \cdot$ Mona Diab-Assaf $^{2} \cdot$ Marie-Paule Vasson $^{1}$. \\ Jérémie Talvas ${ }^{1}$
}

Published online: 24 January 2022

(c) The Author(s) under exclusive licence to University of Navarra 2022

\section{Correction to: Journal of physiology and biochemistry https://doi.org/10.1007/s13105-021-00868-z}

The original version of this article unfortunately contained an incorrect family name; author name "Sahar Al Dekwer" should be "Sahar Aldekwer". Note that this is part of author's late correction included with some in-text corrections.

Publisher's note Springer Nature remains neutral with regard to jurisdictional claims in published maps and institutional affiliations.

The original article can be found online at https://doi.org/10.1007/ s13105-021-00868-z.

Jérémie Talvas

Jeremie.talvas@uca.fr

1 UMR 1019 Human Nutrition Unit, INRAe,

University of Clermont Auvergne, CRNH Auvergne,

63000 Clermont-Ferrand, France

2 Faculty of Sciences II, Lebanese University, Fanar, Lebanon 